\title{
Classical demonstration of atrial flutter with slow ventricular rate captured on echo: an illustration of an important pathophysiological phenomenon
}

\author{
Iranna Hirapur, ${ }^{1}$ Rajeshwari Veeranna Mantgol, ${ }^{2}$ Navin Agrawal $^{3}$
}

${ }^{1}$ Department of Cardiology, R L Jalappa, Narayana Hrudalaya Heart Centre, Kolar, Karnataka, India

${ }^{2}$ Department of

Ophthalmology, R L Jalappa, Narayana Hrudalaya Heart

Centre, Kolar, Karnataka, India ${ }^{3}$ Department of Cardiology, Care Hospital, Surat, Gujarat, India

\section{Correspondence to} Dr Navin Agrawal, drnavinagrawal@gmail.com

Accepted 6 June 2014
CrossMark

\section{To cite: Hirapur I,} Mantgol RV, Agrawal N. BMJ Case Rep Published online: [please include Day Month Year] doi:10.1136/ bcr-2014-205447

\section{DESCRIPTION}

Atrial flutter is a macro-re-entrant tachycardia predisposing to atrial thrombus formation often seen in patients with structural heart disease. ${ }^{1}{ }^{2}$ Atrial flutter with atrioventricular node blockade is a potentially life-threatening cause of bradycardia and decompensation of heart failure usually seen in patients with pre-existing valvular or structural diseases and/or conduction system disease. Diagnosis is usually by ECG. This combination of arrhythmia is rare. We present an interesting echocardiographic illustration of this pathophysiological phenomenon which has been described previously only on ECG.

A 75 -year-old woman presented with symptoms of class IV dyspnoea and presyncope with a pulse rate of $24 \mathrm{bpm}$ with borderline blood pressure (90/ $70 \mathrm{~mm} \mathrm{Hg}$ ).

ECG showed the atrial rate of almost 300 and ventricular rate of around $24 \mathrm{bpm}$ (figure 1). The echo images were interesting and showed a brisk fluttering movement of the mitral valve leaflets 7-10 times before every ventricular contraction (videos 1-3). There was no evidence of valvular abnormality of the heart but overall biventricular contraction was poor. The patient was treated with a permanent pacemaker after which symptoms improved significantly.

The textbook echocardiographic illustration of this rather uncommon but clinically significant pathophysiological phenomenon caused by

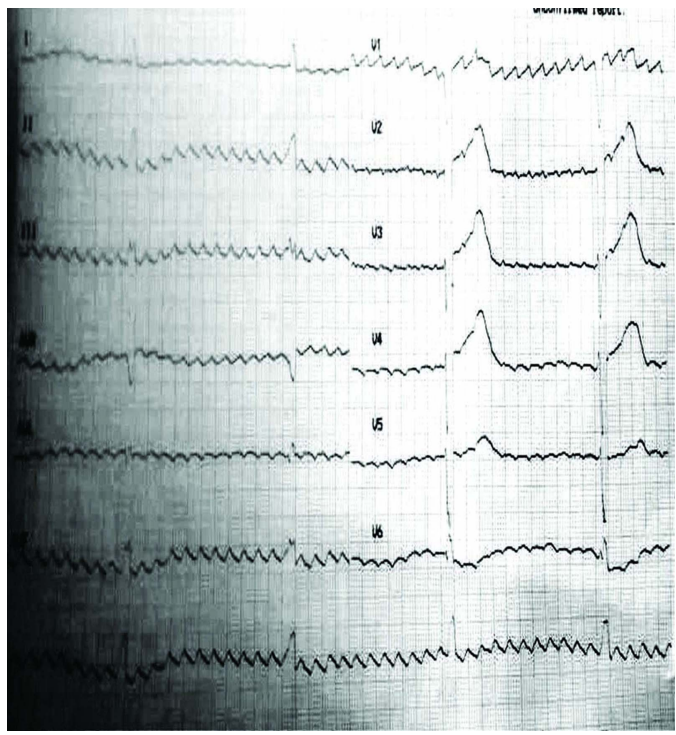

Figure 1 ECG of the patient showing atrial flutter with atrioventricular block and ventricular escape rhythm.

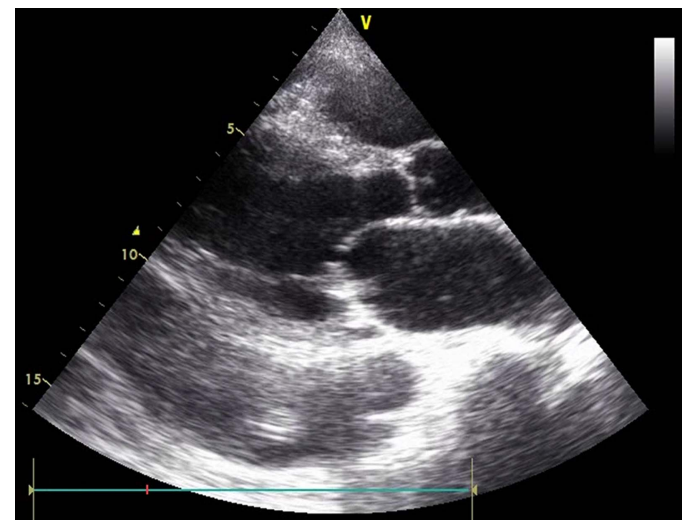

Video 1 Parasternal long axis view showing repeated atrial contraction along with a single ventricular contraction after several atrial beats.

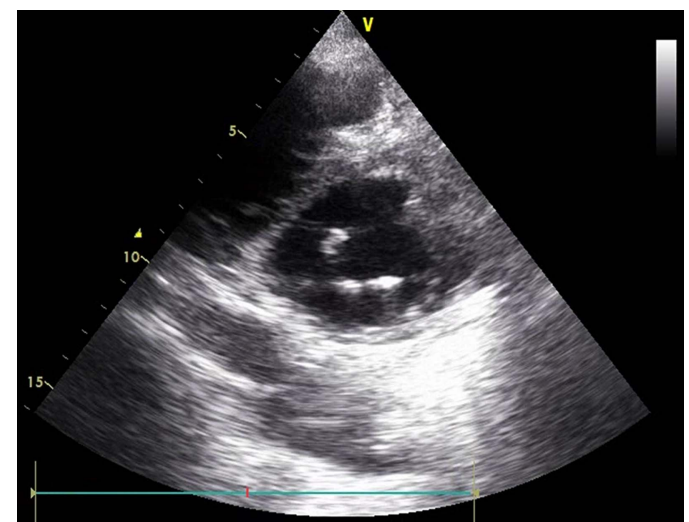

Video 2 Parasternal short axis view illustrating fluttering mitral valve leaflets with intermittent ventricular contractions.

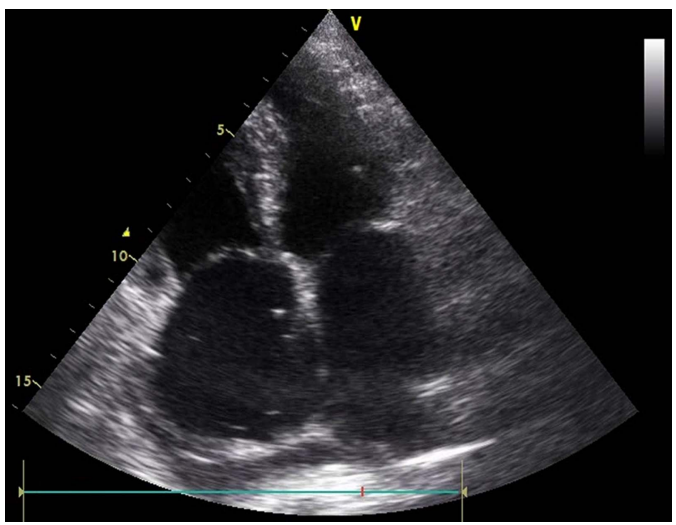

Video 3 Apical four chamber view illustrating the fluttering mitral valve leaflets with few ventricular contractions. 


\section{Learning points}

- Atrial flutter with atrioventricular (AV) node blockade is a potentially life-threatening cause of bradycardia and decompensation of heart failure and the diagnosis is essentially always performed with the help of an ECG.

- Echocardiogram can provide an illustrative documentation of this interesting ECG abnormality and, at the same time, provide knowledge of any structural abnormality of the heart which could have potentially triggered this arrhythmia.

- This image suggests the role of echocardiography in understanding the pathophysiology of atrioventricular arrhythmias, especially those characterised by the loss of AV synchrony, and may help to assess the cause of haemodynamic compromise in these patients. arrhythmia has seldom been previously described and is an interesting learning experience for clinicians and echocardiographers. These images can help to develop a good understanding of the pathophysiology of significant arrhythmias involving atrioventricular dyssynchrony and establish a potential role for echocardiography in diagnosis and management of patients with haemodynamically significant arrhythmias.

Competing interests None.

Patient consent Obtained.

Provenance and peer review Not commissioned; externally peer reviewed.

\section{REFERENCES}

1 Ghali WA, Wasil BI, Brant R, et al. Atrial flutter and the risk of thromboembolism: a systematic review and meta-analysis. Am J Med 2005;118:101-7.

2 Biblo LA, Yuan Z, Quan KJ, et al. Risk of stroke in patients with atrial flutter. Am J Cardiol 2001;87:346-9, A9.

Copyright 2014 BMJ Publishing Group. All rights reserved. For permission to reuse any of this content visit http://group.bmj.com/group/rights-licensing/permissions.

BMJ Case Report Fellows may re-use this article for personal use and teaching without any further permission.

Become a Fellow of BMJ Case Reports today and you can:

- Submit as many cases as you like

- Enjoy fast sympathetic peer review and rapid publication of accepted articles

- Access all the published articles

- Re-use any of the published material for personal use and teaching without further permission

For information on Institutional Fellowships contact consortiasales@bmjgroup.com

Visit casereports.bmj.com for more articles like this and to become a Fellow 